\title{
Using A Dynamic Taylor-Type Rule To Examine The Behavior Of Bond Yields: Some International Evidence
}

William L. Seyfried, Rollins College, USA

\begin{abstract}
A dynamic version of Taylor's rule is applied to the analysis of the behavior of short-term and long-term government bonds in different nations. Results indicate that long-term yields are highly sensitive to inflationary expectations, but support was mixed for short-term maturities. Evidence suggests that short-term rates are more responsive to the output gap than long-term rates for all the countries considered. Taylor's rule appears to provide insight into understanding similarities and differences in the behavior of interest rate on government bonds of different maturities in the countries studied.
\end{abstract}

Keywords: interest rate, Taylor's Rule

\section{INTRODUCTION}

e n 1993, John Taylor proposed a simple rule to capture the underlying factors affecting decision making by the Fed. According to this rule, the optimal federal funds rate begins with an estimate of the longterm, equilibrium federal funds rate. Deviations from this rate should occur when inflation differs from its desired rate or if GDP differs from its potential (the output gap). If inflation rises, the nominal interest rate should rise to maintain the same real rate. In addition, the central bank is likely to raise the rate further in order to increase real interest rates in an attempt to slow down the economy and bring inflation back to its desired rate. Inclusion of the output gap plays two roles. A positive output gap implies that inflationary pressures are building, thus motivating the Fed to raise interest rates to keep inflation in check. A negative output gap is evidence of a weak economy (along with downward pressure on inflation), which may lead the Fed to lower interest rates to stimulate the economy. Judd and Rudebusch (1998) proposed a modified version of Taylor's rule that accounts for a dynamic adjustment mechanism since the interest rate is unlikely to be adjusted immediately to its theoretically optimal rate.

Though financial markets do not make decisions in the same manner as central banks, many of the same factors are taken into account by traders in the bond market. Bond traders desire a sufficient real rate of return. If inflation is expected to rise or inflationary pressure is perceived to be building, the nominal interest rate needs to increase to provide the same real return. This implies that both higher expectations of inflation and a positive output gap should correlate to higher interest rates. Also, economic weakness is likely to result in decreased demand for credit putting downward pressure on interest rates. Changes in interest rates make take some time as markets evaluate the information, thus requiring an adjustment process. Thus, a dynamic version of Taylor's rule should prove useful in examining the behavior of Treasury yields. By examining data from different nations, one can draw inferences as to differences in the behavior of financial markets. Empirical evidence indicates that bond investors do indeed respond to changes in expected inflation when considering long-term securities, though the evidence is mixed for short-term bonds. Yields also respond to indications of economic strength, with short-term rates displaying more sensitivity than long-term rates. In addition, bonds with short maturities tend to display some persistence in the movement of interest rates accompanied by low speeds of adjustment. 


\section{DESCRIPTIVE STATISTICS}

Quarterly data for the respective countries were obtained for the period from the mid-1990s to 2007. Differences in the periods are due to the availability of data. The output gaps are estimates obtained from the respective government agencies (the US Congressional Budget Office, Bank of Canada, and Her Majesty's Treasury). In the case of Australia, potential GDP was estimated using a Hodrick-Prescott Filter in order to derive an estimate of the output gap. Both three-month and ten-year government bond rates using constant maturity were obtained from the respective central banks. Expected inflation was proxied using estimates from the respective central banks based on differences between traditional and inflation-indexed securities. Since the US only began issuing inflation-indexed bonds in 2003, there would have been insufficient data. Thus, for the US, expected inflation was proxied using the Philadelphia Federal Reserve survey of professional economists.

Tables 1a-d present the basic descriptive statistics for each variable. Long-term interest rates, as expected, tended to be higher than short-term interest rates, on average. Small differences can be seen for Australia and the UK while relatively larger differences existed for Canada and the US. Expectations of inflation tended to be lowest in Canada and highest in the UK; Australia and the US displayed similar average rates of expected inflation. As one would expect, the averages of the output gap tended to be close to zero.

Table 1a: Descriptive Statistics: Australia (1996-2007)

\begin{tabular}{|l|c|c|c|}
\hline & Mean & Median & Standard Deviation \\
\hline Interest Rate on 3-month government bond & $5.60 \%$ & $5.48 \%$ & 0.81 \\
\hline Interest Rate on 10-year government bond & $6.01 \%$ & $5.83 \%$ & 0.91 \\
\hline Expected Inflation & $2.65 \%$ & $2.59 \%$ & 0.61 \\
\hline Output Gap & $0.04 \%$ & $-0.03 \%$ & 0.57 \\
\hline
\end{tabular}

Table 1b: Descriptive Statistics: Canada (1996-2007)

\begin{tabular}{|l|c|c|c|}
\hline & Mean & Median & Standard Deviation \\
\hline Interest Rate on 3-month government bond & $3.72 \%$ & $3.90 \%$ & 1.06 \\
\hline Interest Rate on 10-year government bond & $5.19 \%$ & $5.16 \%$ & 0.86 \\
\hline Expected Inflation & $2.32 \%$ & $2.35 \%$ & 0.48 \\
\hline Output Gap & $-0.12 \%$ & $0.05 \%$ & 1.06 \\
\hline
\end{tabular}

Table 1c: Descriptive Statistics: United Kingdom (1994-2007)

\begin{tabular}{|l|c|c|c|}
\hline & Mean & Median & Standard Deviation \\
\hline Interest Rate on 3-month government bond & $5.20 \%$ & $5.19 \%$ & 0.99 \\
\hline Interest Rate on 10-year government bond & $5.77 \%$ & $5.13 \%$ & 1.46 \\
\hline Expected Inflation & $3.33 \%$ & $2.98 \%$ & 0.87 \\
\hline Output Gap & $-0.19 \%$ & $-0.10 \%$ & 0.69 \\
\hline
\end{tabular}

Table 1d: Descriptive Statistics: United States (1992-2007)

\begin{tabular}{|l|c|c|c|}
\hline & Mean & Median & Standard Deviation \\
\hline Interest Rate on 3-month government bond & $4.24 \%$ & $4.66 \%$ & 1.56 \\
\hline Interest Rate on 10-year government bond & $5.55 \%$ & $5.59 \%$ & 1.07 \\
\hline Expected Inflation & $2.67 \%$ & $2.52 \%$ & 0.48 \\
\hline Output Gap & $-0.67 \%$ & $-1.27 \%$ & 1.57 \\
\hline
\end{tabular}

\section{DYNAMIC VERSION OF TAYLOR'S RULE}

First introduced in 1993, Taylor's rule has been the subject of substantial research. From its original simple form with arbitrary coefficients, many variations have since been introduced. Among those who employed versions of Taylor's rule to examine monetary policy were Gerlach and Schnabel (1999); Orphanides (2007), Smets (1998) and Taylor (1999). In its original form, Taylor's rule simply relates the federal funds rate to both the output and inflation gaps (see 1). If inflation rises above its desired level, the Fed should raise the federal funds rate. If GDP 
exceeds its potential, inflationary pressures exist and the Fed should raise the federal funds rate to contain these pressures.

$f_{t}^{*}=\pi_{t}+r_{t}+1 / 2\left(\pi_{t}-\pi_{t}^{*}\right)+1 / 2 y_{t}$

where $\mathrm{f}$ is the federal funds rate; $\pi$ is the inflation rate; $\mathrm{r}$ is the equilibrium real federal funds rate; and $\mathrm{y}$ is the output gap. The coefficients on the original model were chosen by Taylor. Though the model proved effective in explaining the behavior of Fed policy during the first five years of the Greenspan era, subsequent researchers sought instead to estimate the relationship using a model similar to (2).

$f_{t}^{*}=\pi_{t}+r^{*}+B_{1}\left(\pi_{t}-\pi^{*}\right)+B_{2} y_{t}$

Equations (1) and (2) seek to identify how the "optimal" federal funds rate responds to inflation and the output gap. However, the federal funds rate is unlikely to jump to its new optimal level. Thus, further modifications were made to account for interest-rate smoothing. One of the more popular models that took this into account was one that introduced a dynamic adjustment process to account for the speed and persistence of interest rate movements (Judd and Rudebusch, 1998).

$\Delta \mathrm{f}_{\mathrm{t}}=\gamma\left(\mathrm{f}_{\mathrm{t}}^{*}-\mathrm{f}_{\mathrm{t}-1}\right)+\rho \Delta \mathrm{f}_{\mathrm{t}-1}$

Gamma provides an estimate of how quickly the federal funds rate adjusts to its optimal value (f*) while rho is a measure of the persistence of changes in the federal funds (with higher values implying more persistence). That is, once the federal funds rate begins to move in a certain direction, it is likely to continue to move in that direction as it transitions to its new optimal level. Gamma and rho attempt to measure how quickly the rate moves and how long this process takes. When one combines (2) and (3), a dynamic version of Taylor's rule can be estimated:

$\Delta \mathrm{f}_{\mathrm{t}}=\gamma \alpha-\gamma \mathrm{f}_{\mathrm{t}-1}+\rho \Delta \mathrm{f}_{\mathrm{t}-1}+\gamma\left(1+\mathrm{B}_{1}\right) \pi_{\mathrm{t}}+\gamma \mathrm{B}_{2} \mathrm{y}_{\mathrm{t}}$

where $\alpha=\mathrm{r}^{*}-\mathrm{B}_{1} \pi^{*}$.

One can view $\pi$ as either inflation or expected inflation since the Fed seeks to keep inflation in check rather than reacting to it after it already has risen and also that because it seeks to anchor inflationary expectations,.

Though central banks and financial markets differ in terms of structure and the timing of decision making, they share similar concerns and consider similar factors when deciding on the direction of interest rates. Participants in the bond market continually take actions that impact market interest rates and have been referred to as "inflation vigilantes" in that they pay careful consideration to the future direction of inflation. Thus, bond traders pay close attention to signals of inflationary pressure whether it's higher expectations of inflation or an overheating economy as evidenced by GDP exceeding its potential (a positive output gap). Given the similar focus of bond markets and central banks, it would appear that a version of Taylor's rule can provide insight into the behavior of financial markets in setting market interest rates. Therefore, equation (4) can be modified as follows:

$\Delta \mathrm{i}_{\mathrm{t}}=\gamma \alpha-\gamma \mathrm{i}_{\mathrm{t}-1}+\rho \Delta \gamma \mathrm{i}_{\mathrm{t}-1}+\gamma\left(1+\mathrm{B}_{1}\right) \pi_{\mathrm{t}}+\gamma \mathrm{B}_{2} \mathrm{y}_{\mathrm{t}}$

where $\mathrm{i}$ is the interest rate on a government bond.

\section{REVIEW OF THE LITERATURE}

While a considerable amount of research has been undertaken applying Taylor's rule to monetary policy (see above), there has been little application of it to the study of bond markets. A few authors have employed some of the concepts embodied in Taylor's rule to the analysis of market-determined interest rates. Rudebusch et. al. (2006) made use of the output gap and inflation gap to examine the behavior of short-term interest rates. Diebold et. al. (2006) analyzed the movement of interest rates in response to changes in the output gap as well as the difference between inflation and its average. Former President of the Saint Louis Federal Reserve, William Poole (2003), has 
stated that a robust economy increases real interest rates as businesses increase their demand for credit by seeking new funds with which to invest. He also expressed the likelihood of a one-for-one relationship between expected inflation and nominal interest rates (often referred to as the Fisher effect).

Thus, even though there has been little direct application of Taylor's rule to the analysis of bond yields, the concepts underlying Taylor's rule have been employed in previous research. This study applies a dynamic version of Taylor's rule to examine the behavior of securities of different maturities in bond markets in four countries. Comparisons between countries and maturities are made to provide insight into the behavior of the respective financial markets.

\section{EMPIRICAL MODEL AND RESULTS}

Quarterly data from the mid-1990s to 2007 are employed to estimate the model described above (see equation 5). One would expect $B_{1}$ to be equal to one if the Fisher effect holds true. That is, a one percent increase in expected inflation leads to a corresponding one percent increase in the nominal interest rate on government securities. $\mathrm{B}_{2}$ is expected to be positive since relative economic strength puts upward pressure on real interest rates. The magnitude of the coefficient would indicate how sensitive the interest rate is to economic strength (or weakness). The speed of adjustment is estimated by $\gamma-$ a higher value for $\gamma$ would be evidence of a higher speed of adjustment to the appropriate value based on macroeconomic conditions. The degree of persistence is estimated by $\rho-$ a high value for $\rho$ indicates that once interest rates start moving in a certain direction, they continue moving that way for an extended period of time.

Standard econometric tests for the validity of the model revealed no econometric issues for either maturity for any country. The empirical results can be seen in Tables 2 and 3. To test for the statistical significance of expected inflation and the output gap, one needs to employ indirect least squares since the estimation of (5) yields $\gamma$ $\gamma_{2}$ and $\gamma\left(1+\mathrm{B}_{1}\right)$ as the respective coefficients. Estimated values for $\mathrm{B}_{1}$ and $\mathrm{B}_{2}$ can be obtained by modifying both terms using the estimated coefficient on the lagged interest rate $(\gamma)$.

Table 2a: Australia: Three-Month Government Bond

\begin{tabular}{|l|c|c|}
\hline & Estimated coefficient & t-stat or $\chi^{2}$ \\
\hline Speed of adjustment & $0.36^{* * *}$ & 2.26 \\
\hline Degree of persistence & $0.29^{* *}$ & 3.68 \\
\hline Expected inflation & $0.32^{*}$ & 4.70 \\
\hline Output gap & $0.46^{*}$ & \\
\hline $\mathrm{R}^{2}=0.60$ & & \\
\hline Test for Fisher Effect: $\mathrm{X}^{2}=16.73^{* *}$ & \\
\hline
\end{tabular}

Table 2b: Canada: Three-Month Government Bond

\begin{tabular}{|l|c|c|}
\hline & Estimated coefficient & t-stat or $\chi^{2}$ \\
\hline Speed of adjustment & $0.21^{* *}$ & 3.84 \\
\hline Degree of persistence & $0.33^{* *}$ & 2.95 \\
\hline Expected inflation & $0.72^{* *}$ & 9.71 \\
\hline Output gap & $0.53^{* *}$ & 4.54 \\
\hline $\mathrm{R}^{2}=0.52$ & & \\
\hline Test for Fisher Effect: $\mathrm{X}^{2}=1.68$ & & \\
\hline
\end{tabular}

Table 2c: UK: Three-Month Government Bond

\begin{tabular}{|l|c|c|}
\hline \multicolumn{2}{|c|}{ Table 2c: UK: Three-Month Government Bond } & t-stat or $\chi^{2}$ \\
\hline Speed of adjustment & Estimated coefficient & 4.20 \\
\hline Degree of persistence & $0.16^{* * *}$ & 5.31 \\
\hline Expected inflation & $0.53^{* *}$ & 0.33 \\
\hline Output gap & 0.18 & 14.40 \\
\hline $\mathrm{R}^{2}=0.49$ & $0.72^{* *}$ & \\
\hline Test for Fisher Effect: $\mathrm{X}^{2}=7.01^{*}$ & & \\
\hline
\end{tabular}


Table 2d: US: Three-Month Government Bond

\begin{tabular}{|l|c|c|}
\hline & Estimated coefficient & t-stat or $\chi^{2}$ \\
\hline Speed of adjustment & $0.16^{* *}$ & 4.35 \\
\hline Degree of persistence & $0.61^{* *}$ & 3.91 \\
\hline Expected inflation & $0.82^{*}$ & 21.08 \\
\hline Output gap & $0.66^{* *}$ & \\
\hline $\mathrm{R}^{2}=0.53$ & & \\
\hline Test for Fisher Effect: $\mathrm{X}^{2}=0.15$ & & \\
\hline
\end{tabular}

Note: t-statistic used for speed of adjustment and degree of persistence; $\mathrm{X}^{2}$ used for expected inflation and output gap. $* *$ indicates $1 \%$ level of significance, * indicates $5 \%$ level of significance

Similar results were found for each country in the model of the three-month government bonds. All but one of the coefficients for each variable were found to be statistically significant. Expected inflation was positive and significantly related to the interest rate in each country except UK with comparable coefficients found for Canada and the US. The output gap, as expected, had a positive and significant impact on the short-term interest rate for all the countries studied. Speeds of adjustment were relatively low and comparable for Canada, UK and the US with Australia's speed being somewhat higher. Interest rates displayed smaller degrees of persistence in Australia and Canada than UK and US. Test for the Fisher effect reveal that it was not evident in Australia and the UK since the estimated coefficient of expected inflation was significantly less than one. Support for the Fisher effect was found in Canada and the US.

Table 3a: Australia: Ten-Year Government Bond

\begin{tabular}{|l|c|c|}
\hline & Estimated coefficient & t-stat or $\chi^{2}$ \\
\hline Speed of adjustment & $0.30^{* * *}$ & 4.73 \\
\hline Degree of persistence & 0.16 & 2.34 \\
\hline Expected inflation & $0.57^{* *}$ & 0.79 \\
\hline Output gap & 0.29 & \\
\hline $\mathrm{R}^{2}=0.37$ & & \\
\hline Test for Fisher Effect: $\mathrm{X}^{2}=1.67$ & \multicolumn{2}{|}{} \\
\hline
\end{tabular}

Table 3b: Canada: Ten-Year Government Bond

\begin{tabular}{|l|c|c|}
\hline & Tstimated coefficient & t-stat or $\chi^{2}$ \\
\hline Speed of adjustment & $0.13^{*}$ & 2.01 \\
\hline Degree of persistence & 0.02 & 0.12 \\
\hline Expected inflation & -0.25 & 0.10 \\
\hline Output gap & 0.29 & 0.37 \\
\hline $\mathrm{R}^{2}=.08$ & & \\
\hline Test for Fisher Effect: $\mathrm{X}^{2}=2.37$ & & \\
\hline
\end{tabular}

Table 3c: UK: Ten-Year Government Bond

\begin{tabular}{|l|c|c|}
\hline & Estimated coefficient & t-stat or $\chi^{2}$ \\
\hline Speed of adjustment & $0.26^{* *}$ & 0.93 \\
\hline Degree of persistence & 0.08 & 0.78 \\
\hline Expected inflation & $0.74^{* * *}$ & 16.60 \\
\hline Output gap & $0.44^{* *}$ & 4.85 \\
\hline $\mathrm{R}^{2}=0.54$ & & \\
\hline Test for Fisher Effect: $\mathrm{X}^{2}=2.96$ & & \\
\hline
\end{tabular}

Table 3d: US: Ten-Year Government Bond

\begin{tabular}{|l|c|c|}
\hline & Estimated coefficient & t-stat or $\chi^{2}$ \\
\hline Speed of adjustment & $0.44^{* *}$ & 2.13 \\
\hline Degree of persistence & $0.26^{* *}$ & 2.34 \\
\hline Expected inflation & $1.03^{* * *}$ & 31.21 \\
\hline Output gap & $0.37^{* *}$ & \\
\hline $\mathrm{R}^{2}=0.35$ & & \\
\hline Test for Fisher Effect: $\mathrm{X}^{2}=0.01$ & \multicolumn{2}{|l|}{} \\
\hline
\end{tabular}


Table 3e: Canada: Ten -Year Government Bond, Augmented with the Change in the US Ten-Year Treasury Bond

\begin{tabular}{|l|c|c|}
\hline & Estimated coefficient & t-stat or $\chi^{2}$ \\
\hline Speed of adjustment & 0.04 & 0.88 \\
\hline Degree of persistence & 0.03 & 0.34 \\
\hline Expected inflation & 2.07 & 0.24 \\
\hline Output gap & 0.04 & 7.69 \\
\hline Lagged change in US R & $0.66^{* * *}$ & \\
\hline $\mathrm{R}^{2}=.62$ & \multicolumn{2}{|}{} \\
\hline Test for Fisher Effect: $\mathrm{X}^{2}=1.91$ & \multicolumn{2}{|l}{} \\
\hline
\end{tabular}

Note: t-statistic used for speed of adjustment and degree of persistence; $\mathrm{X}^{2}$ used for expected inflation and output gap. $* *$ indicates $1 \%$ level of significance, * indicates $5 \%$ level of significance

Results for long-term interest rates (ten-year government bonds) revealed some differences in their behavior between nations. Perhaps the most notable result was the lack of significance of the model in the case of Canada. Lucia, et.al. (2008) found that, whereas short-term interest rates in Canada were primarily affected by domestic economic factors, long-run interest rates were highly correlated with those in the United States. Thus, the model for Canada was re-estimated including the change in US 10-year Treasury bonds. The results confirm their findings as the coefficient of the change in the 10-year US Treasury bond was highly significant (see table 3e).

For the remaining countries, expected inflation was positive and significantly related to long-term yields in every case. Meanwhile, the output gap had a positive and significant effect in the UK and US. Similar speeds of adjustment were detected for Australia and the UK while the US displayed a slightly higher speed of adjustment. A significant degree of persistence was only found in the case of US Treasury bonds. Evidence in support of the Fisher effect was found in every nation.

When comparing the results for short-term and long-term yields, some noticeable differences were found. The output gap had a smaller effect on long-term yields than short-term yields in every country. The impact of a one percent output gap was about a 50 basis point increase in the three-month government bond yield in Australia and Canada and approximately a 70 basis point increase in three-month rates in the UK and US. Meanwhile, little effect was detected on long-term rates in Australia and Canada and about a 40 basis point increase in the UK and US. However, with the exception of Canada, expected inflation had a larger effect on long-term rates than short-term rates, with support for the Fisher effect detected for long-term interest rates in every nation..

Little difference was detected in the speed of adjustment for short-term and long-term yields except for the US where long-term yields displayed a higher speed of adjustment. However, the degree of persistence was found to be lower for long-term interest rates in every country. An insignificant degree of persistence was found in for long-term interest rates in every nation but the US whereas a positive degree of persistence was noted for short-term interest rates in each case. For short-term yields, the degree of persistence was about 0.3 for Australia and Canada and slightly above one-half in the UK and US. Together, this suggests that short-term interest rates tend to move in one direction longer than long-term rates, while they both adjust to their "appropriate" value as determined by macroeconomic conditions at a similar rate (except in the case of the US).

\section{SUMMARY AND CONCLUSIONS}

The dynamic Taylor-type rule presented in this paper provides insight into the behavior of the yield on three-month and ten-year government securities in the countries studied. There was mixed evidence regarding the existence of the Fisher effect. Whereas support was found in all the countries when considering the behavior of long-term interest rates, only half of the countries exhibited the Fisher effect in the case of short-term government securities. It appears that ten-year government bonds are more sensitive to expected inflation than those with shortterm maturities. This makes sense since higher rates of inflation are likely to have more detrimental effects on longterm securities. Economic strength, as measured by the output gap, tends to have a more significant impact on short-term interest rates than long-term rates. This difference is likely due to long-term interest rates not being as sensitive to short-term fluctuations in economic activity while short-term rates are more responsive to current economic conditions. 
Long-term interest rates displayed a lower degree of persistence in each country. One reason for this is probably due to short-term rates being more correlated to overnight rates targeted by central banks which tend to display persistence as central banks implement their policy using interest-rate smoothing (small and steady changes in targeted interest rates). Little difference in terms of speeds of adjustment was found between bonds of different maturities.

Though results were similar across countries, some differences should be noted. Short-term yields were more sensitive to inflationary expectations in Canada and the US than Australia and UK. Unlike in other countries, yields on ten-year bonds displayed persistence in the US. Confirming the finds of Lucia, et. al. (2008), there's evidence that long-term bonds in Canada are largely driven by US financial markets instead of domestic factors whereas domestic factors helped to explain the behavior of long-term interest rates in the other nations studied. Taylor's rule appears to provide insight into understanding similarities and differences in the behavior of interest rate on government bonds of different maturities in the countries studied.

\section{REFERENCES}

1. Diebold, F.X., G.P. Rudebusch, and B. Aruoba, "The Macroeconomy and the Yield Curve: A Dynamic Latent Factor Approach,” Journal of Econometrics, 2006, no. 131, 309-338.

2. Gerlach, Stefan and Gert Schnabel, "The Taylor Rule and Interest Rates in the EMU Area: A Note," Bank for International Settlements, Working Paper No. 73, August 1999.

3. Judd, John P. and Glenn G. Rudebusch, "Taylor's Rule and the Fed: 1970-1997," Federal Reserve Bank of San Francisco Economic Review, 1998, no. 3, 3-16.

4. Lucia, K., S. Price, E. Wong, and R. Startz, "The Changing Relation between the Canadian and U.S. Yield Curves," University of Washington, Department of Economics Working Paper, http://www.econ.wshington.edu/user/startz/Working_Papers/Changing\%Relation\%20May\%2008\%20wp.p df

5. $\quad$ Orphanides, Athanasios, "Taylor Rules," Board of Governors of the Federal Reserve System, January 2007. http://www.athanasioorphanides.com/taylor22.pdf

6. Poole, William, "Prospects and Risks in the Bond Market," Federal Reserve Bank of Saint Louis, 2003. http://stlouisfed.org/news/speeches/2003/9_04_03.html

7. Rudebusch, Glenn D., Eric T. Swanson, and Tao Wu, "The Bond Yield 'Conundrum' from a MacroFinance Perspective," Bank of Japan, 2006. http://www.imes.boj.or.jp/english/publication/mes/2006/me24-s1-6.pdf

8. Smets, Frank, “Output Gap Uncertainty: Does It Matter for the Taylor Rule?” BIS Working Paper, Bank for International Settlements, Monetary and Economic Development, Basle, Switzerland \#60, November 1998.

9. Taylor, John, "Discretion Versus Policy Rules in Practice," Carnegie-Rochester Conference Series on Public Policy, 1993, 39, 195-214.

10. Taylor, John, "The Robustness and Efficiency of Monetary Policy Rules as Guidelines for Interest Rate Setting by European Central Bank," 1999. http://www.stanford.edu/ johntayl/Papers/taylor2.pdf. 
International Business \& Economics Research Journal - March 2009

Volume 8, Number 3

NOTES 